\title{
Modeling of maritime agitation for the design of maritime infraestructures: the case study of madeira archipelago
}

\section{Roberto Silva Gonçalves roberto90goncalves@hotmail.com University of Madeira (UMa), Funchal, Portugal. \\ Rafael Freitas Camacho rafaelfreitascamacho@oulook.com University of Madeira (UMa), Funchal, Portugal. \\ Sérgio Lousada \\ slousada@staff.uma.pt \\ University of Madeira (UMa), Funchal, Portugal. \\ Rui Alexandre Castanho alexdiazbrown@gmail.com University of Extremadura, Badajoz, Spain.}

\begin{abstract}
The modeling of maritime agitation is a valuable tool regarding the dimensioning of maritime works - spatial planning processes - according to with the Maritime Space (POEM). Based on a probabilistic analysis of significant heights, resulting in the design wave for this dimensioning, it allows to avoid situations of structures galvanization and, consequently, flooding of urbanized areas. The maritime weather along the Autonomous Region of Madeira Island (RAM) it presents the ideal features to develop this typology of study. In this regard, it is pivotal to perform an analysis of the oceanographic and geotechnical features of Madeira Archipelago regarding the ports of Funchal, Caniçal, Porto Moniz and Porto Santo. Through informatics available data by the governmental entities, it has been possible to develop a mapping of the maritime agitation occurring on the case study sites. With the research, and considering the lack of recent bathymetric studies, and wave buoy with incomplete characterization, it has been defined the relevance of a probabilistic analysis based on a return period of a 100 years, enabling to well-design and planning that typology of infrastructures; once at a regional reality it fosters to promote a considerable increase in the life's standards of the urban agglomerations.
\end{abstract}

KEYWORDS: Design; Maritime Agitation; Planning; Ports; Spatial Planning. 


\section{INTRODUCTION}

The characterization of maritime climate and the determination of wave height are pivotal factors once they represent fundamental aspects of safety and comfort of the population, not only economically, but also regarding tourism, mainly, because our dependence on maritime conditions to safeguard these values. A poor analysis of such parameters can lead to partial or total destruction of infrastructures as walls, piers, marinas, and ports - since these are the first to suffer the consequences of maritime agitation - as well as occupied flood areas, damaging homes, business, and services - i.e. tourism, socio-economic basis in the region - leading to significant costs to restore population life's standards (Earl et al., 2013; Djouder\&Boutiba, 2017; Pullen et al., 2017; Sánchez-Clay et al., 2017).

In Madeira Island, one of the most recent occurrences is the case of Lugar de Baixo marina, located in the municipality of Ponta do Sol being a port infrastructure of relative importance, was inaugurated during the year of 2004. The port has been operational for a short period of time, due to sea conditions present on the site, conditions that caused the partial destruction of the protective wall of the marina and massive damage to the infrastructure, several attempts to solve the problem have been carried out, still they were unsuccessful, demonstrating once again the importance of a well-develop study of the territorial conditions to assess the feasibility of building an infrastructure that is pivotal for the region - once such typology of infrastructure provides employment opportunities, business, and leisure, justifying the investment (Cunha \& Pinto, 2010; Didier \&Neves, 2010; Lee et al.., 2010; Peng et al., 2011; Earl et al., 2013; Diab et al., 2017).

Similar cases as in Poland (Zaucha, 2014), United Kingdom (Adam et al., 2016), India (Patra et al., 2016), Algeria (\& Boutiba Djouder, 2017) and China (Zheng et al., 2017), prompted the respective researchers tostudy the local maritime agitation and its consequences contributing with data to assist urban/maritime planning.

Such events demonstratethe urgency to know in depth maritime agitation to ensure the functionality of port structures as well as to provide safety to the local urban agglomerations. The effects associated with the wave height, that define the agitation, depending on physiographic and climatic features of the coast as well as the urban occupation of coastal areas. It compellingly leads to a good planning and maritime spatial planning, focusing on the interaction that occurs along the coast and between the sea and coastal structures, to safeguard the safety and comfort of the population (Vivero et al., 2009; Calado et al., 2010; DGPM, 2011; Becker-Weinberg, 2015; Stelzenmüller et al., 2017).

Principlesregarding planning should be taking into account - i.e. perform flood mapping areas, establishment of specific conditions to the coast regarding land use and also the creation of maritime agitation protectiveand dissipative structures strategically positioned and well-designed - however, such principles require technical support that only a well-developed study may provide (Meiner, 2010; DGPM, 2011; Schaefer \&Barale, 2011; Fernandes et al., 2017; Tsilimigkas \& 
Thus, the present research has considered critical features and steps, such as: defining maritime infrastructures; description of a methodology aiming a determination of long-term estimates and comparative analysis; defining calculation methodologies and applying to retrieved data of the coast of RAM.

\section{METHODOLOGY}

The used methodology (Figure 1)is based on the establishment of general laws that allow the study of recurring natural phenomena, through case study research method (Yin, 1994; Levy, 2008) and also quantitative (Amador, 2010).

Figure 1 - Methodology

\begin{tabular}{|c|c|c|c|}
\hline Research & Case Study & Analysis & $\begin{array}{c}\text { Discussion and } \\
\text { Conclusions }\end{array}$ \\
\hline $\begin{array}{l}\text { - Literature Review } \\
\text { - Relevant } \\
\text { parameters }\end{array}$ & $\begin{array}{l}\text { - Selection criteria } \\
\text { - Site analysis }\end{array}$ & $\begin{array}{l}\text {-Wave height, } \\
\text { propagation and } \\
\text { direction } \\
\text { - Planning and } \\
\text { design processes }\end{array}$ & $\begin{array}{l}\text { - Maritime agitagion } \\
\text {-Socioeconomic } \\
\text { contribution }\end{array}$ \\
\hline
\end{tabular}

\section{Literature review}

Over the years several studies have been put forward, aimingthe development of knowledge relating to maritime agitation, maritime space planning and design of maritime infrastructures (Pinto\&Neves, 2003; Shah et al., 2004; IHB, 2005; Lancaster \& Franco, 2006; Wedge \& Pinto, 2010; Lee et al.., 2010; DGPM, 2011; Earl et al., 2013;Castanho et al., 2016; Instituto Hidrográfico, 2016; Castanho et al., 2017; Diab et al., 2017; Fernandes et al., 2017; Zheng et al., 2017), pivotal to the development of the present research.

\section{Maritime agitation}

Maritime agitation is characterized by being a physical action. The wave height, intensity, and direction properly registered define the maritime agitation. The bathymetry of the area is strongly influenced by this action, due to the interaction of maritime agitation with the sea floor, easily changed in a brief period, by accretion or erosion phenomena, which are responsible for modifications along the whole coast, through a lengthy process of friction between seawater and rocks, these rocks eventually wear out and turn into small grains, these being transported by the waves. The bathymetry is fundamental to the study of coastal areas, because it allows to evaluate the surfing area, consequently, determine the location of port structures (IHB, 2005; Lancaster \& Franco, 2006; Wedge \& Pinto, 2010; Earl et al., 2013; InstitutoHidrográfico, 2016).

Waves are formed by pressure oscillations on the surface of the sea. The strains vary depending on the wind and rely on three properties related to the previous: intensity - the higher the wind speed, the higher will be the waves. A wave of $1.0 \mathrm{~m}$ requires that the wind has a speed greater than $10.0 \mathrm{~m} / \mathrm{s}$; length - 
to exist wave formation it is necessary that the wind occurs during some time, i.e., for the wind conditions of $20.0 \mathrm{~m} / \mathrm{s}$ is required two days for the formation of a stable wave; extension - it is necessary that the wind thrives in a wide area for the formation of a stable spectrum (IHB, 2005; Lancaster \& Franco, 2006; Wedge \& Pinto, 2010; Earl et al., 2013; InstitutoHidrográfico, 2016). The main properties that characterize the waves are: significant Height - HS (meters) - based on a set time period, significant height represents the average of the top third of all waves analyzed during this period;

$$
H_{s}=4 \sqrt{m_{0}}
$$

Where:

$\mathrm{m}_{0}$ - zeroth-order moment (area) of the wave spectrum.

- Peak Period - $\mathrm{T}_{\mathrm{p}}$ (seconds) - the period of a wave is defined as the time that two successive crests take to go through a fixed point. The peak period allows to characterize the period associated with the dominant wave system;

- Average period - $\mathrm{T}_{02}$ (seconds) -represents the weighted average of the entire energy spectrum;

$$
T_{02}=\sqrt{\frac{m_{0}}{m_{2}}}
$$

Where:

$\mathrm{m}_{2}$ - second-order moment (area) of the wave spectrum.

- Average direction- THTP1 (degrees) - represents the weighted average of the direction of origin of the entire energy spectrum, measured in degrees relative to the geographic North, with a positive signal in the clockwise direction.

\section{Study area}

\section{General features}

The Madeira Archipelago is located in the Atlantic Ocean, in the African plate, between latitudes $30^{\circ} 01^{\mathrm{N}}$ and $33^{\circ} 31^{\prime} \mathrm{N}$ and longitudes of $15^{\circ} 51^{\prime} \mathrm{W}$ and $17^{\circ} 30^{\prime} \mathrm{W}$ relative to the Greenwich Meridian, $978 \mathrm{~km}$ southwest (SW) of Lisbon, $450 \mathrm{~km}$ North (N) of the Canary Islands and the $700 \mathrm{Km}$ West (W) from the African coast (France \& Almeida, 2003; Ribeiro \& Ramalho, 2009; Pullen et al., 2017).

It can be divided into two groups of Islands, the Northern Group located in ocean environment comprises the islands of Madeira, Porto Santo, and Desertas and the South Group comprises the Selvagens Islands, located near the 
archipelago of the Canary Islands and the African continent, having a total area of 796.80 km2 (France \& Almeida, 2003; Ribeiro \& Ramalho, 2009; Pullen et al., 2017).

Madeira Island has an area of $736.00 \mathrm{~km} 2$, featuring an elongated shape, with $58.0 \mathrm{~km}$ in East-West direction and $23.0 \mathrm{~km}$ in the North-South direction. The morphology was strongly influenced by the volcanic structures, sea level changes, the climate, and exposure to erosive agents, this combination of factors contributes a lot to a very rugged terrain, being the highest point Pico Ruivo with an altitude of 1862.0 m (France \& Almeida, 2003; Ribeiro \& Ramalho, 2009; Pullen et al., 2017).

The Porto Santo island situated to the North-East (NE) of the archipelago, $500.0 \mathrm{~km}$ from the African coast and $1000.0 \mathrm{~km}$ of the European continent, has an area of $42.26 \mathrm{~km}^{2}$, being the smallest inhabited island of the archipelago. The morphology features a lower relief compared to Madeira, being the highest point Pico do Facho with an altitude of 517.0 m(France \& Almeida, 2003; Ribeiro \& Ramalho, 2009; Pullen et al., 2017).

\section{Case studies}

Madeira ports are a reference point for ships that cross the transatlantic routes, with a privileged location in the Atlantic Ocean (Figure 2).

Figure 2- Location of ports and wave buoys (adapted from de ifcn.madeira.gov.pt).

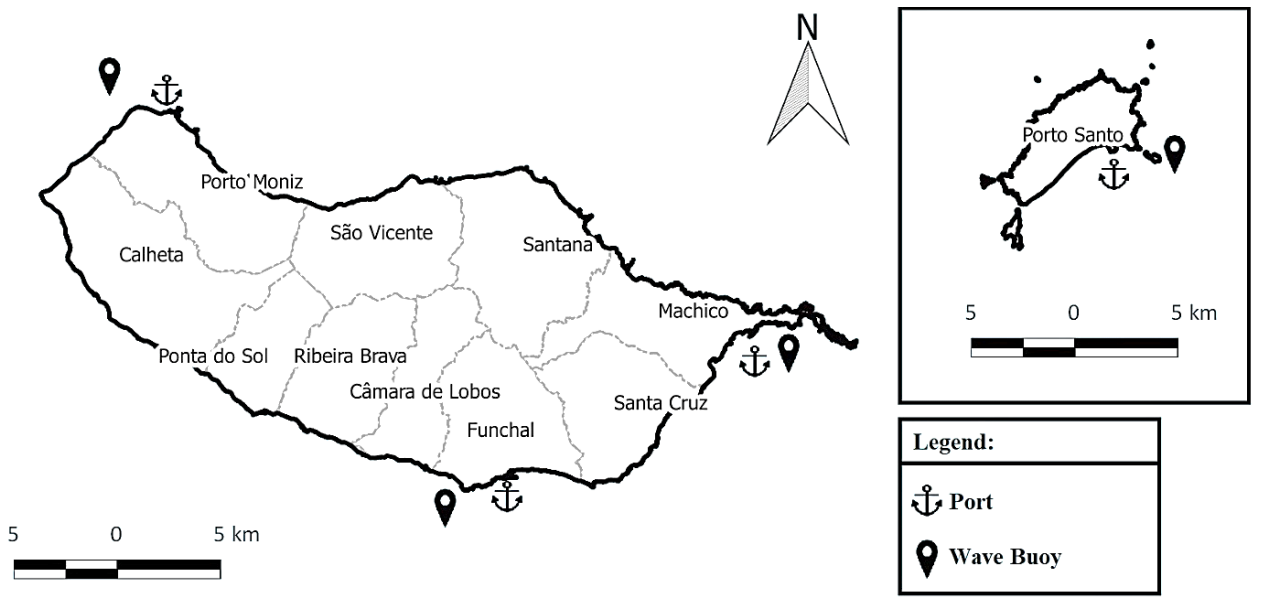

Funchal's port is the main port structure of the Autonomous Region of Madeira (RAM), currently a port infrastructure for cruise ships, warships and school ships (APRAM, 2017).By the other hand,the port of Caniçal is intended for commerce, witha supply function, through the container ships, fishing vessels and fuel stock through the Fuel Logistics Terminal (APRAM, 2017).Porto Moniz's port is the main connecting point of the North Coast of Madeira Island, being destined to maritime activities of the population of the North Coast; allowing the connection by air to emergency situations through the Heliport, due to the long distance from this location to the Hospital of Funchal (APRAM, 2017).Regarding Porto Santo's port, this is defined by a mixed infrastructure as it is used by cruise ships and cargo vessels have a pier intended for fishing vessels and recreational 
vessels and own a cement terminal, being a small-scale port structure considering the resident population (APRAM, 2017).

Directional wave buoys measure the vertical acceleration of the movements of the sea surface and also the direction of waves propagation. The acquired data is transmitted via radio to receiver stations that receive and decode the data, generating the parameters that best characterize maritime agitation in real time (IHB, 2005; Lancaster \& Franco, 2006; Wedge \& Pinto, 2010; Earl et al., 2013; Instituto Hidrográfico, 2016).

Data acquisition is performed at scanning intervals of $0.78125 \mathrm{~s}$, this being registered in two ways: time series of $10 \mathrm{~min}$, processed in real time, at intervals of one to two minutes, these time series are of the utmost importance for the control of port structures, to navigators and maritime sports practitioners; time series of $30 \mathrm{~min}$, processed in 3-hour intervals (whenstormoccurs, it's processed in one-minute intervals, toevaluate the situation). These series are typically used for studies regarding the maritime agitation because the records have a higher duration which gives more reliable statistics (Instituto Hidrográfico, 2016).

The records have the following parameters: spectral and directional $\left(\mathrm{H}_{\mathrm{mo}}-\right.$ significant height, meters; $\mathrm{T}_{02}$-average period, seconds; $\mathrm{P}_{\mathrm{T}}$-peak period, seconds; $T_{\text {htp }}$-direction associated with the average peak period, degrees; $S_{\text {prtp }}$-dispersion in the peak period, degrees); calculated by the direct method $\left(\mathrm{H}_{\mathrm{s}}\right.$-significant height, the third highest average wave height from zero upward, meters; $\mathrm{H}_{\max }{ }^{-}$ maximum height of zero ascendants in registration, meters; $T_{\text {hs }}$-average of the periods corresponding to the waves that were used in the calculation of $\mathrm{H}_{\mathrm{s}}$, seconds; $T_{h \max }$ - corresponding period to $H_{\max }$, seconds; $T_{z}$-average periods of zero ascendants, seconds; $T_{\max }-$ maximum periodregistered, seconds) (Instituto Hidrográfico, 2016).

RAM currently offers two operationalwave buoys (Funchal and Caniçal), these being administered by APRAM, and two others (Porto Moniz and Porto Santo) out of service (Figure 2 and Table 1).

Table 1- Location of wave buoys.

\begin{tabular}{|c|c|c|c|c|}
\hline Location & Caniçal & Funchal & Porto Moniz & Porto Santo \\
\hline Latitude & $32^{\circ} 43^{\prime} 12^{\prime \prime} \mathrm{N}$ & $32^{\circ} 37^{\prime} 06^{\prime \prime} \mathrm{N}$ & $32^{\circ} 53^{\prime} 28^{\prime \prime} \mathrm{N}$ & $33^{\circ} 02^{\prime} 08^{\prime \prime} \mathrm{N}$ \\
\hline Longitude & $16943^{\prime} 42^{\prime \prime} \mathrm{W}$ & $16956^{\prime} 30^{\prime \prime} \mathrm{W}$ & $17012^{\prime} 17^{\prime \prime} \mathrm{W}$ & $16^{\circ} 15^{\prime} 40^{\prime \prime} \mathrm{W}$ \\
\hline Depth & $108.0 \mathrm{~m}$ & $100.0 \mathrm{~m}$ & $90.0 \mathrm{~m}$ & - \\
\hline
\end{tabular}

\section{Data assessment}

The study of maritime climate is crucial in the design of port structures, allowing to determine the conditions for the projected wave, through historical data. The maritime agitation regime was established based on the existing wave buoys data, made available by the Administração dos Portos da RegiãoAutónoma da Madeira (APRAM). The characterization of maritime agitation was made based on the significant wave height and direction associated with the average peak period. 
simplify the weather calculations and uniformed. Regarding direction, it was considered a maximum of sixteen directions based on the wind rose. Each direction covers a sector with an amplitude of $22.5^{\circ}$, including in each direction all waves that occur in the sectors, in intervals of $\pm 11.25^{\circ}$

\section{Annual regime}

The conditions of the annual maritime agitation were based on the percentages of occurrence of significant heights, peak periods and average directions, being the displayed graphics relative to Funchal. Also in Funchal, the predominant significant wave height is between $0.5 \mathrm{~m}$ and $1.0 \mathrm{~m}$, occurring $52.88 \%$ of the time. The largest wave height record is between $5.5 \mathrm{~m}$ and $6.0 \mathrm{~m}$, arising on nine occasions (Figure 3 ).

Figure 3 - Annual significant wave height $\left(\mathrm{H}_{\mathrm{MO}}\right)$ frequency for Funchal.

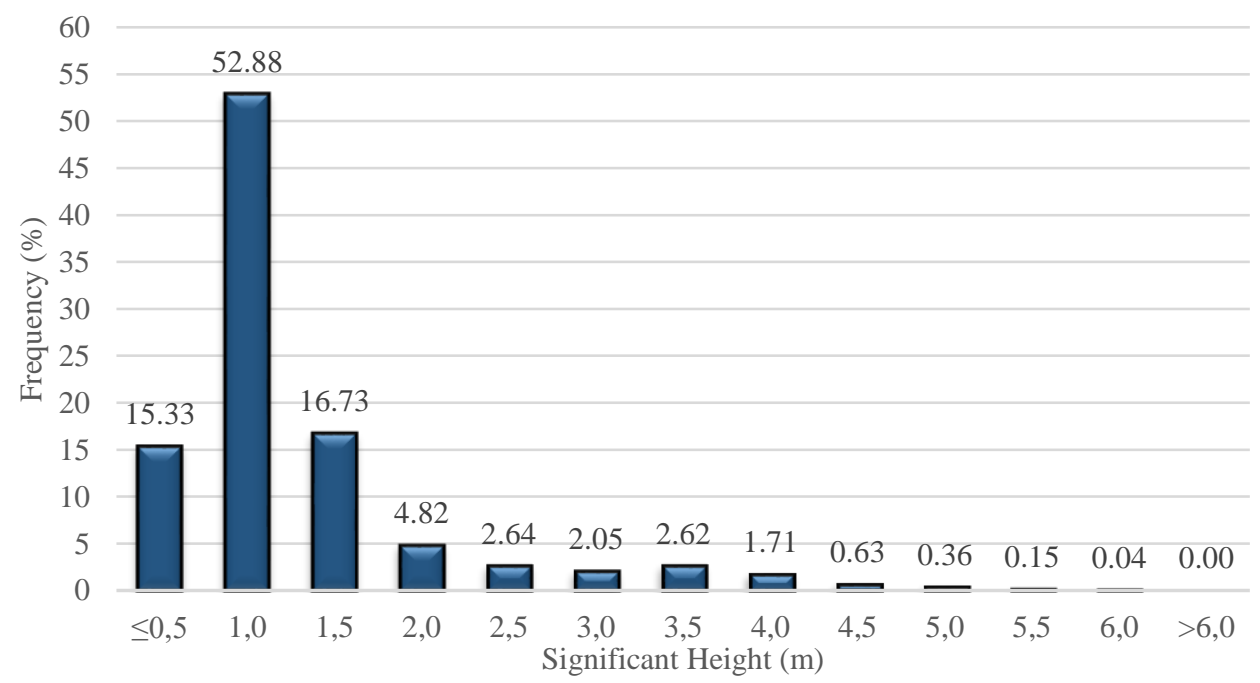

The peak period is a parameter that varies greatly over time, leading to similar occurrence percentages throughout the year (Figure 4).

Figure 4 - Annual peak period $\left(T_{P}\right)$ frequency for Funchal.

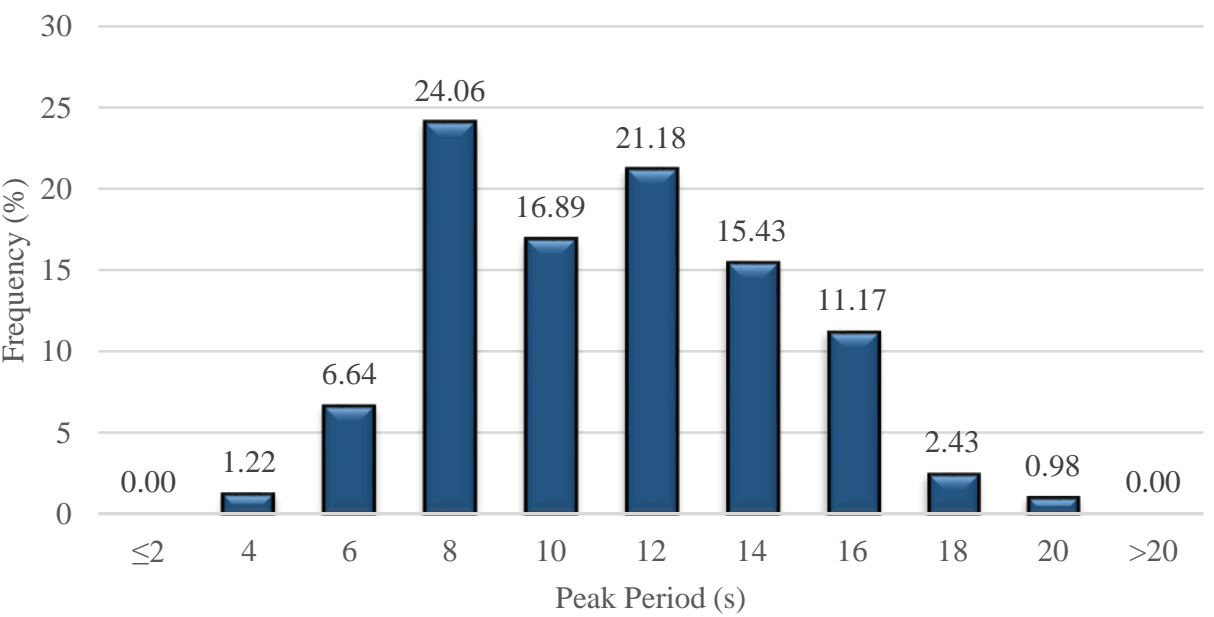


The prominent wave propagation in Funchal is in the South-West quadrant. Approximately $41.55 \%$ of the waves rise from West and $12.93 \%$ from South-Southwest (SSW). In the South-East quadrant, 13.11\% rises from East and 4.47\% from East-Southeast (ESE) (Figure 5).

Figure 5- Annual directional frequency for Funchal.

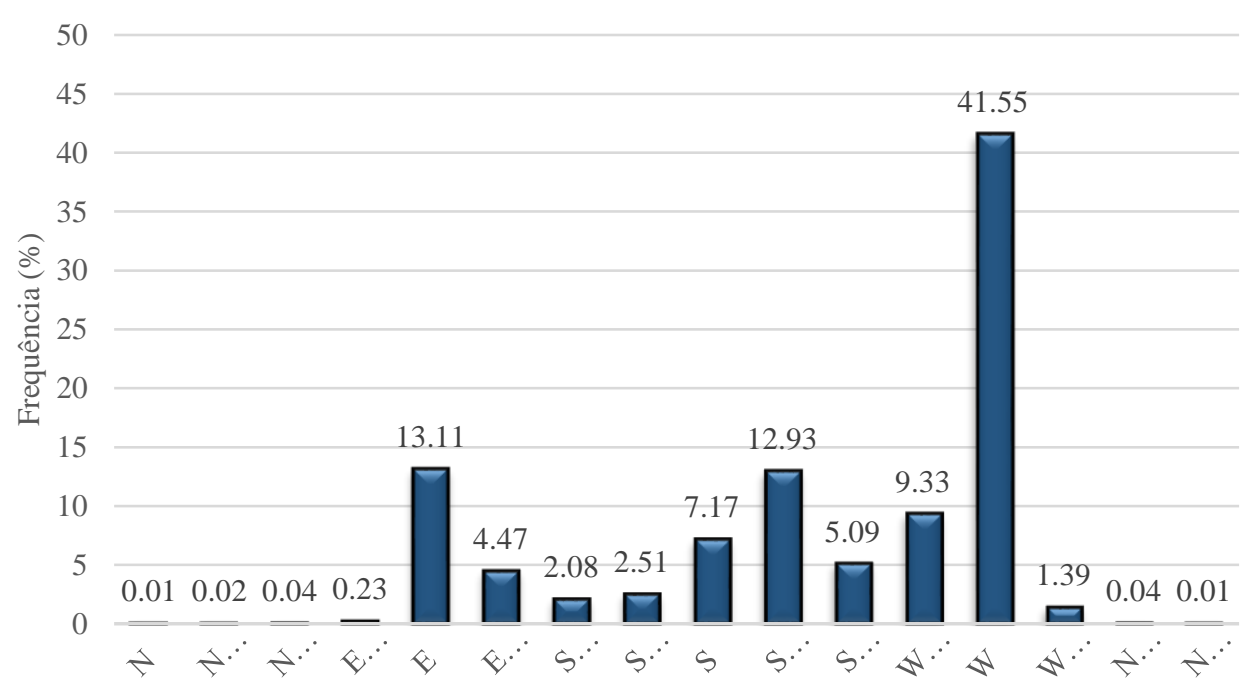

The prominent significant wave height rises approximately $20.0 \%$ of the time from West and approximately $10.0 \%$ from East (Figure 6).

Figure 6- Annual significant wave height $\left(\mathrm{H}_{\mathrm{MO}}\right)$ direction for Funchal.

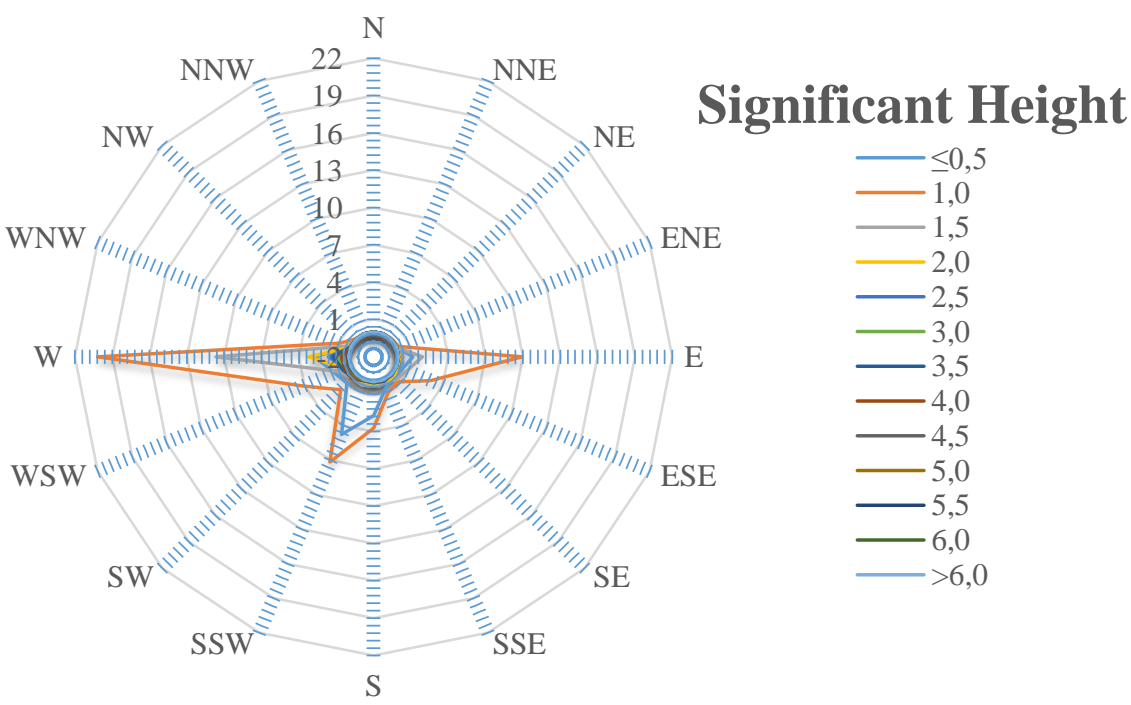

\section{Probabilistic analysis}

Aiming to characterize a given local maritime agitation, is used values of significant wave heights for the annual maximum in coastal areas, through the records made by wave buoys, present on the site, provided by APRAM.

Probabilistic analysis is the process of adjusting statistical laws in relation to the significant wave heights and estimation of these values in relation to the 
probability of exceedance function, following a determined methodology (Figure 7).

Figure 7- Probabilistic analysis methodology

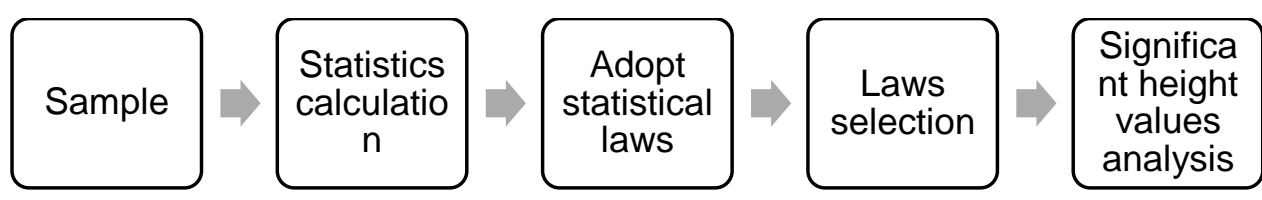

Weibull's law was used once it is the best formulation that characterizes the maritime agitation, i.e. the law that has the best fit to the reduced normal distribution values in relation to significant annual peak heights (Table 2). Since it isan infrastructure of major importance opts for a return period of 100 years.

Table 2 - Estimated wave height, for a given return period.

\begin{tabular}{|c|c|c|c|c|c|c|}
\hline \multirow{2}{*}{ Port } & \multirow{2}{*}{ Law } & \multicolumn{5}{|c|}{ Return periods (Years) } \\
\cline { 3 - 7 } & & $\mathbf{5}$ & $\mathbf{1 0}$ & $\mathbf{2 5}$ & $\mathbf{5 0}$ & $\mathbf{1 0 0}$ \\
\hline \multirow{2}{*}{ Funchal } & 5.3 & 5.8 & 6.5 & 6.9 & 7.3 \\
\hline Caniçal & \multirow{4}{*}{ Weibull } & 3.6 & 3.9 & 4.2 & 4.3 & 4.4 \\
\cline { 3 - 7 } & & 5.1 & 5.3 & 5.4 & 5.4 & 5.4 \\
\hline Porto Moniz & & 4.6 & 5.0 & 5.6 & 6.2 & 6.7 \\
\hline Porto Santo & & & & & & \\
\hline
\end{tabular}

Carol

The Carol program features the oceanographic variables defined from a chronological series. The basic layout of the program is organized into three modules (Figure 8): preambular information, data descriptive statistics; characterization of the average regime of avariable; characterization of the extremes of a variable (Sanger Institute, 2017). 
Figure 8 - Structure of each module.

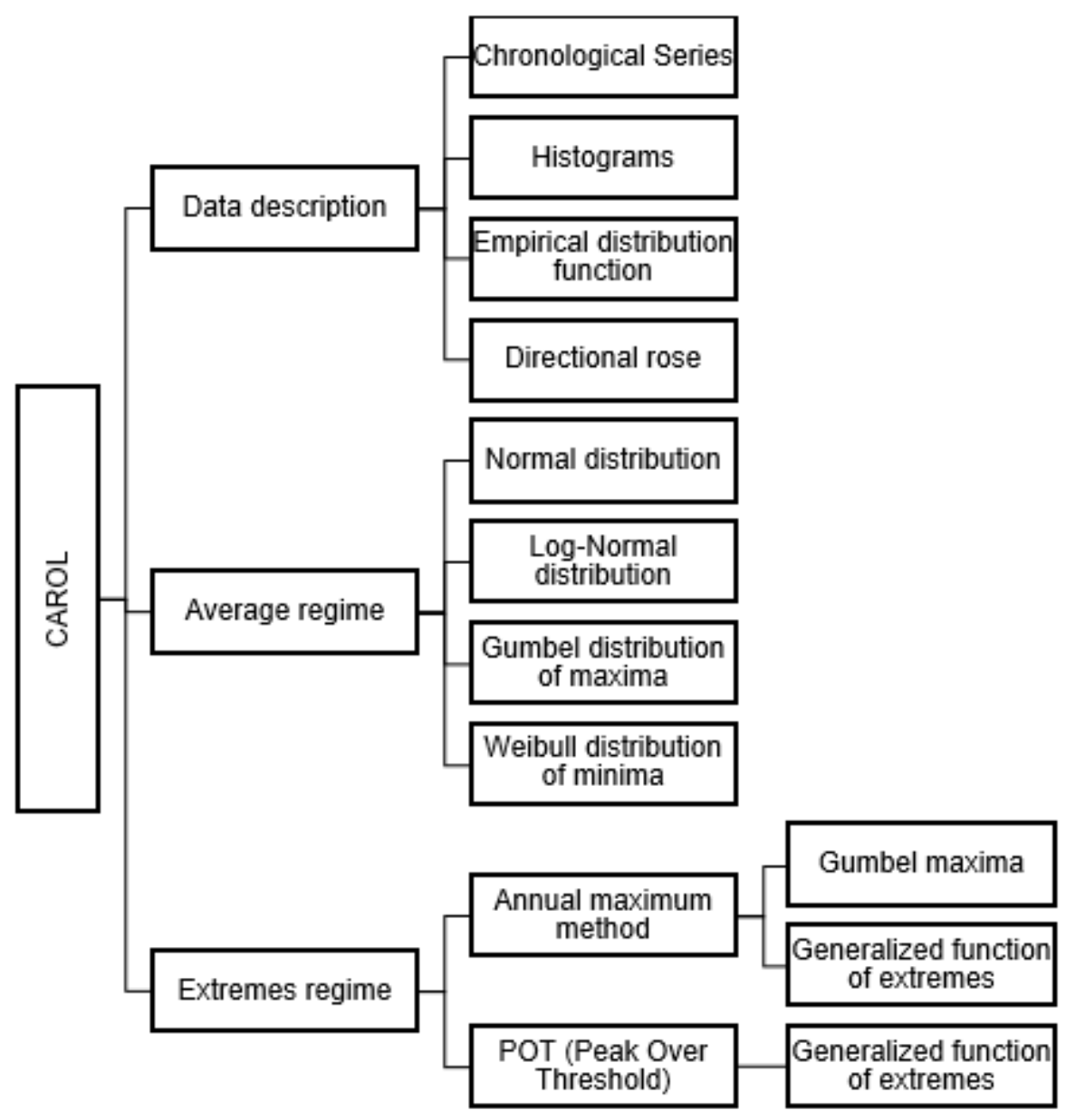

Mopla

Mopla program is a numerical model that makes it possible to do a morphodynamical study of the coast. Simulates the propagation of waves from a set depth to the coastline, over a period of time, the factor of extreme importance to analyze the propagation of waves in order to determine the conditions to which the port structures will be exposed (IHCantabria, 2017).

From the analysis made by the maritime climate, it was possible to determinate the sets of conditions to which the ports are subjected to. For each of the ports were defined the three directions of waves which the ports were more exposed to and the peak period to the highest wave height.

The tide in RAM fits in the semidiurnal type. According to the tide table for 2016, published by Instituto Hidrográfico(IH) and considering the average sea level rise is necessary an increase of $0.1 \mathrm{~m}$, being the following astronomical tide levels to be considered (Table 3). 
Table 3- Astronomic tide levels.

\begin{tabular}{|c|c|}
\hline \multicolumn{2}{|c|}{ Data (m) } \\
\hline PM max. & +2.74 \\
\hline PM AV & +2.45 \\
\hline PM AM & +1.87 \\
\hline NM & +1.40 \\
\hline BM AM & +0.94 \\
\hline BM AV & +0.36 \\
\hline BM min. & +0.07 \\
\hline
\end{tabular}

The wave height was defined through probabilistic analysis for a return period of 100 years. According to these factors were defined the various cases to be examined in each of the ports, including the port of Funchal (Table 3), the port of Caniçal (Table 4) and the port of Porto Moniz (Table 5).

Table 4- Analysed cases for the Port of Funchal.

\begin{tabular}{|c|c|c|c|c|c|}
\hline \multicolumn{7}{|c|}{ Porto of Funchal } \\
\hline Mesh & Direction & Cases & $\mathbf{T}_{\mathbf{p}}(\mathbf{s})$ & Tide & $\mathbf{H}_{\mathbf{s}} \mathbf{( m )}$ \\
\hline \multirow{3}{*}{ M0 } & \multirow{3}{*}{$\mathrm{W}$} & $\mathrm{A} 1$ & 16 & $\mathrm{PM}+2.74$ & 7.3 \\
\cline { 3 - 6 } & \multirow{3}{*}{$\mathrm{S}$} & $\mathrm{A} 2$ & 16 & $\mathrm{BM}+0.07$ & 7.3 \\
\cline { 3 - 6 } & & $\mathrm{B} 1$ & 16 & $\mathrm{PM}+2.74$ & 7.3 \\
\cline { 3 - 6 } & \multirow{3}{*}{$\mathrm{E}$} & $\mathrm{C} 2$ & 16 & $\mathrm{BM}+0.07$ & 7.3 \\
\cline { 3 - 6 } & & $\mathrm{C} 2$ & 16 & $\mathrm{PM}+2.74$ & 7.3 \\
\hline
\end{tabular}

Table 5 - Analysed cases for the Port of Caniçal.

\begin{tabular}{|c|c|c|c|c|c|}
\hline \multicolumn{6}{|c|}{ Porto of Caniçal } \\
\hline Mesh & Direction & Cases & $T_{p}(s)$ & Tide & $\mathrm{H}_{\mathrm{s}}(\mathrm{m})$ \\
\hline \multirow{6}{*}{ M1 } & \multirow{2}{*}{$\mathrm{S}$} & D1 & 10 & $\mathrm{PM}+2.74$ & 4.4 \\
\hline & & D2 & 10 & $\mathrm{BM}+0.07$ & 4.4 \\
\hline & \multirow{2}{*}{ ESE } & E1 & 10 & $\mathrm{PM}+2.74$ & 4.4 \\
\hline & & E2 & 10 & $\mathrm{BM}+0.07$ & 4.4 \\
\hline & \multirow{2}{*}{ SW } & F1 & 10 & $\mathrm{PM}+2.74$ & 4.4 \\
\hline & & F2 & 10 & $\mathrm{BM}+0.07$ & 4.4 \\
\hline
\end{tabular}

Table 6 - Analysed cases for the Port of Porto Moniz.

\begin{tabular}{|c|c|c|c|c|c|}
\hline \multicolumn{6}{|c|}{ Port of Porto Moniz } \\
\hline Mesh & Direction & Cases & $T_{p}(s)$ & Tide & $H_{s}(m)$ \\
\hline \multirow{8}{*}{ M2 } & \multirow{2}{*}{$\mathrm{N}$} & G1 & 16 & $\mathrm{PM}+2.74$ & 5.4 \\
\hline & & G2 & 16 & $\mathrm{BM}+0.07$ & 5.4 \\
\hline & \multirow{2}{*}{ NW } & $\mathrm{H} 1$ & 16 & $\mathrm{PM}+2.74$ & 5.4 \\
\hline & & $\mathrm{H} 2$ & 16 & $\mathrm{BM}+0.07$ & 5.4 \\
\hline & \multirow{2}{*}{ W } & 11 & 16 & $\mathrm{PM}+2.74$ & 5.4 \\
\hline & & 12 & 16 & $\mathrm{BM}+0.07$ & 5.4 \\
\hline & \multirow{2}{*}{ NE } & J1 & 16 & $\mathrm{PM}+2.74$ & 5.4 \\
\hline & & $J 2$ & 16 & $\mathrm{BM}+0.07$ & 5.4 \\
\hline
\end{tabular}


The analysis of the wave propagation in the port of Porto Santo has not been implemented because APRAM doesn't have the bathymetry of the respective port and, also, because the data obtained by the wave buoydoesn't allow a viable evaluation of the maritime agitationthat the port is subject to due to her location.

\section{RESULTS}

The results from the study of wave propagation produced in Mopla program for the port of Funchal (Table 6), along with the remaining studied ports, particularly the ports of Caniçal and Porto Moniz, follow the same procedure and providing similar results.

The results obtained at the port of Funchal are shown in Tables 6 and 7. For a better characterization of the wave height occurring in this port, it was divided into two areas, North Pier and South Pier. The coordinates $(x, y, z)$ represent the location where the greatest wave heights at the port are described in the column Coordinates. Based on the various cases, described earlier in Table 3, it shows that for a significant wave height of $7.3 \mathrm{~m}$, for a return period of 100 years and a peak period of $16 \mathrm{~s}$, obtained wave heights require that the protective wall of the port structurehas a height superior to $9.0 \mathrm{~m}$ (Tables 6 and 7).

Table 7- Results for the Port of Funchal (North Pier).

\begin{tabular}{|l|c|c|c|c|c|c|c|c|}
\hline \multirow{3}{*}{ Mesh } & \multirow{3}{*}{ Pier } & Coordinates & \multicolumn{5}{|c|}{ Wave Height } \\
\cline { 3 - 9 } & & & A1 & A2 & B1 & B2 & C1 & C2 \\
\hline \multirow{3}{*}{ M0 } & \multirow{3}{*}{ NorthPier (N) } & $(321056.44,3613598.56,-4.47)$ & 6.0 & 4.0 & 6.1 & 3.9 & 6.1 & 3.8 \\
\cline { 3 - 9 } & $(320990.03,3613573.02,-5.39)$ & 5.9 & 4.7 & 6.6 & 4.6 & 5.7 & 4.6 \\
\cline { 3 - 9 } & $(320956.83,3613547.48,-5.47)$ & 5.4 & 4.5 & 6.9 & 5.1 & 5.1 & 4.9 \\
\cline { 3 - 9 } & $(320724.41,3613470.87,-3.79)$ & 5.0 & 4.0 & 6.1 & 4.0 & 7.2 & 4.9 \\
\cline { 3 - 9 } & $(320757.61,3613496.41,-5.39)$ & 5.0 & 3.9 & 5.8 & 3.9 & 7.1 & 5.1 \\
\hline
\end{tabular}

Table 8 - Results for the Port of Funchal (South Pier).

\begin{tabular}{|c|c|c|c|c|c|c|c|c|}
\hline \multirow{2}{*}{ Mesh } & \multirow{2}{*}{ Pier } & \multirow{2}{*}{ Coordinates } & \multicolumn{6}{|c|}{ Wave Height } \\
\hline & & & A1 & A2 & B1 & B2 & C1 & C2 \\
\hline \multirow{5}{*}{ Mo } & \multirow{5}{*}{ South Pier (S) } & $(320093.55,3613087.80,-7.88)$ & 8.2 & 6.6 & 8.1 & 6.7 & 7.8 & 6.1 \\
\hline & & $(320990.03,3613138.88,-3.61)$ & 7.0 & 7.2 & 8.1 & 7.6 & 7.4 & 7.4 \\
\hline & & $(320658.00,3613138.88,-6.01)$ & 6.6 & 6.6 & 8.6 & 8.6 & 7.6 & 7.6 \\
\hline & & $(321122.85,3613164.42,-2.14)$ & 6.2 & 4.8 & 8.1 & 5.6 & 9.1 & 5.8 \\
\hline & & $(321089.64,3613138.88,-5.38)$ & 6.7 & 6.6 & 8.0 & 8.3 & 8.2 & 8.4 \\
\hline
\end{tabular}

The graphical data obtained through the program Mopla, to M0 mesh and C1 case, represents the most adverse situation in the port of Funchal, both on the North Pier and on the South Pier.

The port of Funchal is referenced in Figure 9, between the coordinates 1500 to 2400 on in the horizontal axis and 1800 to 2600 in the vertical axis. The North Pier is between coordinates 2000 to 2400 coordinates in the $\mathrm{x}$-axis and the South Pier between 1500 to 1800 coordinates.Figure 9 represents the wave heights that occur according to the waves propagation along the coast of Funchal in $\mathrm{MO}-\mathrm{C} 1$ case, originating fromEast quadrant. The wave height varies as it approaches the 
coast, due to the morphology of the area in question and to the progressive reduction of the depth, these being the main factors affecting the waves propagation.

The North Pier is exposed along its extension to waves between $4.0 \mathrm{~m}$ and $5.0 \mathrm{~m}$ high, except for a small fraction in which is subject to larger undulation between $6.0 \mathrm{~m}$ and $7.0 \mathrm{~m}$. Regarding the South Pier, it's more exposed compared to the North Pier, with waves ranging from $7.0 \mathrm{~m}$ to $9.0 \mathrm{~m}$ high.

Figure 9 - Wave height, case $\mathrm{MO}-\mathrm{C} 1$.

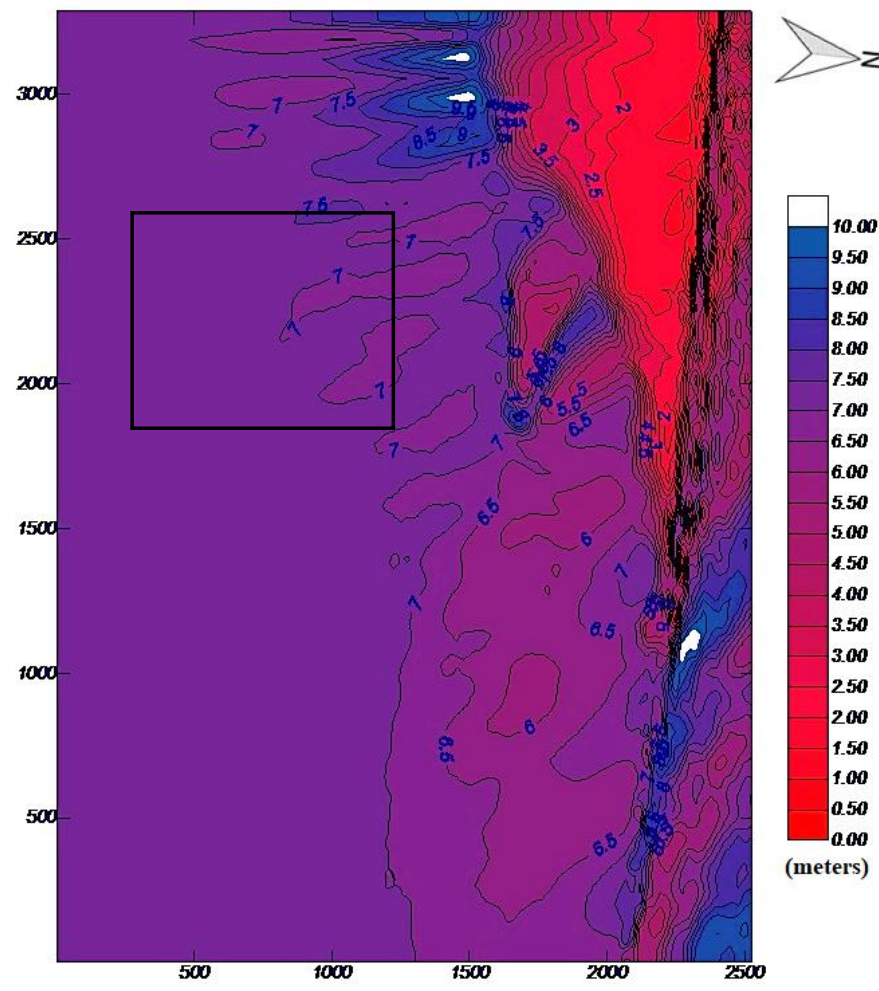

Figure 10 shows the wave heights propagation along the coast of Funchal. Noting that when these hit the coast generate a refraction of that wave. This propagation varies depending on the source of the waves, in this case, from East. Despite the East undulation being less frequent to occur, it is in this direction that the greatest wave heights that port of Funchal is subjected to. 
Figure 10 - Wave height propagation, case M0-C1.

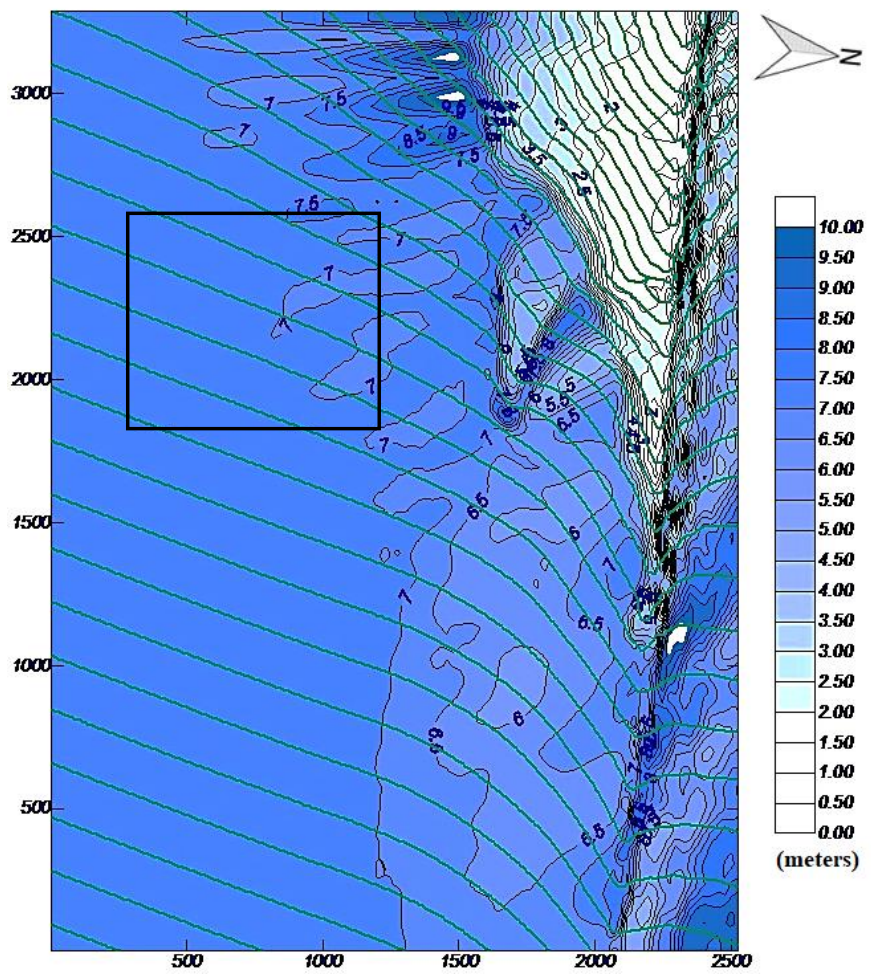

Figure 11 displays the propagation direction along the bathymetry of Funchal. The wave hits the coast at a depth between-0.1 m and $5.0 \mathrm{~m}$ and suffers a change of direction, which can be seen in the representation of the arrows with opposite directions on blank areas.

Figure 11 - Wave direction, case MO-C1.

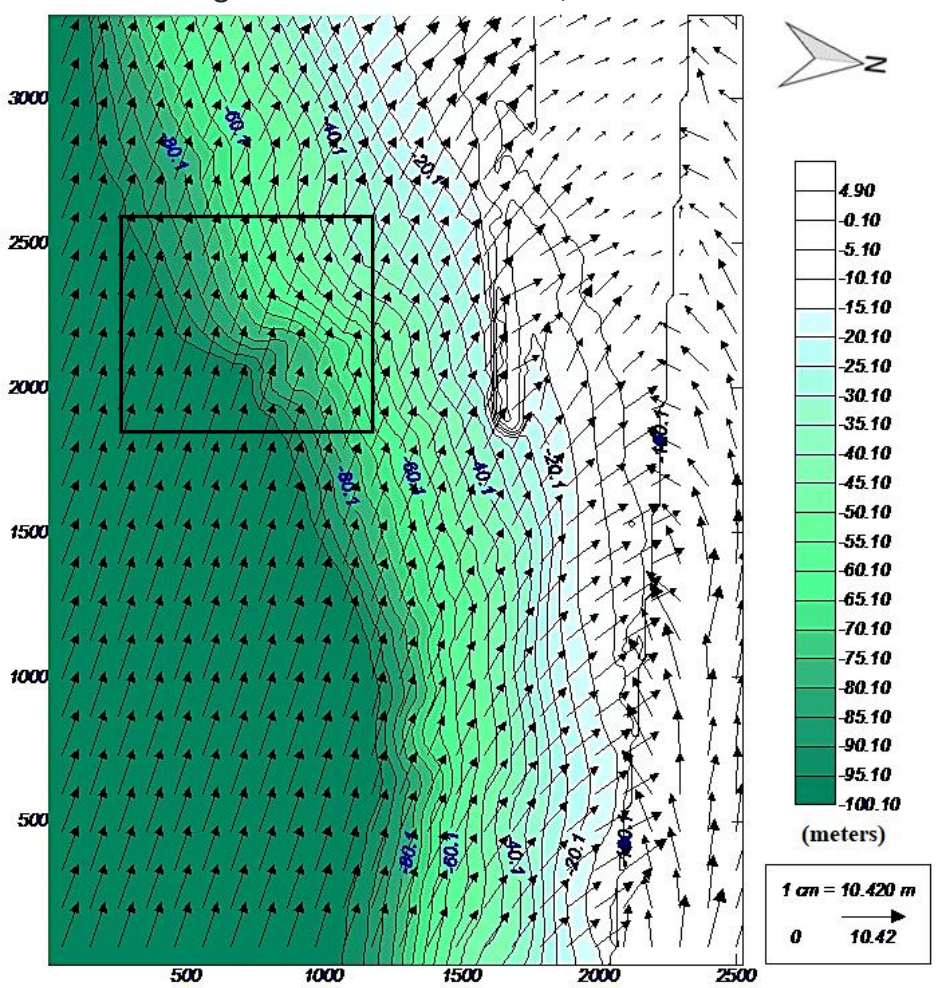




\section{DISCUSSIONAND CONCLUSIONS}

Through the study it is possible to identifysimilarities among situations that hampered the process, related to insufficient research and domain of RAM waterfront - i.e. long periods of inoperability of wave buoys (the last records made by the buoy located in Caniçal were carried out in 2012, only returning to operate at the beginning of the year to 2016, with a four-year period without records and in Porto Moniz and Porto Santo, are not carried out records from 2012 and 2013, respectively); the buoy of Porto Santo is located in a position where it is simultaneously affected by currents from the northern hemisphere and the southern hemisphere not being able to access correctly the records; lack/omission of detailed bathymetric survey of the island of Porto Santo, only being effected inside the port through dredging operations andregarding the bathymetric survey of Funchal, Caniçal and Porto Moniz this was effected in the year 2005, not existing registration of new survey of the locations in question, even though the recent changes that port of Funchal was subjected to; and the operability of FunchalNorth Pier being exposed, without any kind of protection, to maritime agitation from South and Southeast.

The above-mentioned events are intended to contribute positively to develop future studies of this nature, without questioning the public and/or private efforts made towards this issue over the years.

Regarding the outcomes, the Port of Funchal is located on the South coast of Madeira Island, being exposed to maritime agitation predominantly from the Southwest quadrant (SW), about $56.0 \%$ of the time, $23.0 \%$ affected from the South (S) quadrant and approximately $20.0 \%$ from the Southeast quadrant (SE); the records made by the wave buoy of Funchal shows that the greatest wave heights range from $5.5 \mathrm{~m}$ and $6.0 \mathrm{~m}$, representing $0.04 \%$ of the total records; wave heights recorded in $92.0 \%$ of the time range from less than $0.5 \mathrm{~m}$ to $2.5 \mathrm{~m}$.

So, the maritime agitation in the Funchal's port is characterized by a relatively moderate annual average regime. Regarding the seasonal regime, the prominent maritime agitation arises in winter and spring, having been recorded the largest wave height in this last season. Also, and taking into consideration the bathymetry, the morphology around the port of Funchal and a return period of 100 years, it may be exposed to the following heights: on the South Pier, from the Southwest quadrant, $8.2 \mathrm{~m}$ waves, from South with approximately $8.6 \mathrm{~m}$ and from Southeast waves $9.1 \mathrm{~m}$ high, being the most unfavourable situation; on the North Pier, exposed predominantly to Southeast waves, the most unfavourable situation corresponding to waves $7.2 \mathrm{~m}$ high.

The study enables a well-develop characterization of this site and his future reference, although more frequently the waves come from the Southwest, it was verified that the situation with greater gravity (greater wave height) is from Southeast; such characterization is seen as pivotal to plan and manage these typologies of infrastructures.

Regarding the commercial port of the region, Port of Caniçal, maritime agitation arises from the following directions: Southwest, South and Southeast, having a higher incidence from South, as was recorded in about half of the time; the records performed shows that the greatest wave heights go from $4.0 \mathrm{~m}$ to 5.0 $\mathrm{m}$, having appeared on two occasions; the predominant waves in Caniçal varies 
between values less than $0.5 \mathrm{~m}$ up to $2.5 \mathrm{~m}$ appearing in $99 \%$ of the time, being the case of a moderate annual maritime agitation, while at the seasonal level it should be noted that the period of greatest maritime agitation arises in winter, having been recorded the highest wave height of this season.

Concerning the study of the wave propagation that corresponds to the most unfavorable situation at the port of Caniçal, refers to maritime agitation from Southeast with waves $6.9 \mathrm{~m}$ high; in the other directions, arises from the South with $6.5 \mathrm{~m}$ high and from the Southwest with $5.7 \mathrm{~m}$.

The Port of Porto Moniz is located on the North coast of Madeira Island, and is subject to maritime agitation coming from North, Northwest (NW) and Northeast (NE), exposed mostly to North (54\%) and Northwest (43\%) undulation; the highest recorded wave heights are between the $4.5 \mathrm{~m}$ and $5.0 \mathrm{~m}$ high, verified in about $3.0 \%$ of the time; maritime agitation at this location could be considered at moderate to high annual average regime, because the predominant wave heights are in the range between $2.5 \mathrm{~m}$ and $5.0 \mathrm{~m}$, occurred in about $58.0 \%$ of the time; in terms of waves propagation, the most unfavourable case in the Port of Porto Moniz, refers to the Northwest direction waves $8.9 \mathrm{~m}$, from the North waves $6.8 \mathrm{~m}$ and the Northeast waves $7.8 \mathrm{~m}$ high.

The North coast of Porto Santo is exposed to maritime agitation from North and Northeast, and the North's dominant with $62.0 \%$ of occurrence; despite Porto Santo showing moderate annual maritime conditions with waves ranging between $0.5 \mathrm{~m}$ to $2.5 \mathrm{~m}$ high, it also features a large number of higher waves, so it could beconsidering a moderate to high maritime agitation.

Regarding seasonal conditions, these do not show changes between the various seasons, only to point out that in the summer period the sea conditions which arise are predominantly low, ranging between $1.0 \mathrm{~m}$ and $2.5 \mathrm{~m}$, in the spring the undulation occurs in most cases between $1.0 \mathrm{~m}$ and $2.5 \mathrm{~m}$, having been recorded a higher number of wave heights greater than $2.5 \mathrm{~m}$, compared to the other seasons, verifying small oscillations.

It is concluded that the North coast of Madeira is subject to unfavourable maritime conditions in comparison to the South coast, justifying the location of ports of greater economic/tourist importance, namely, the Port of Funchal and the Port of Caniçal, which itself demonstrates the effects and importance of a good urban/maritime planning, supported by a a well-develop study/research of the maritime agitation, where with the simple decision of positioning a port reduces the risk situations to the population and for the structure itself.So, the present research is seen as a helpful tool, not only for planners but also for the decision-makers regarding maritime infrastructure location and management. 


\title{
Modelagem de agitação marítima para o projeto de infra-estruturas marítimas: 0 estudo de caso do arquipélago da Madeira
}

\begin{abstract}
RESUMO
A modelagem da agitação marítima é uma ferramenta valiosa no que diz respeito ao dimensionamento de obras marítimas - processos de ordenamento do território - de acordo com o Espaço Marítimo (POEM). Com base em uma análise probabilística de alturas significativas, resultando na onda de design para este dimensionamento, permite evitar situações de galvanização de estruturas e, conseqüentemente, inundações de áreas urbanizadas. O clima marítimo ao longo da Região Autónoma da llha da Madeira (RAM) apresenta as características ideais para desenvolver esta tipologia de estudo. A este respeito, é fundamental realizar uma análise das características oceanográficas e geotécnicas do arquipélago da Madeira em relação aos portos do Funchal, Caniçal, Porto Moniz e Porto Santo. Através de dados informáticos disponíveis pelas entidades governamentais, foi possível desenvolver um mapeamento da agitação marítima ocorrida nos sites de estudo de caso. Com a pesquisa e considerando a falta de estudos batimétricos recentes e a bóia ondulatória com caracterização incompleta, foi definida a relevância de uma análise probabilística com base em um período de retorno de 100 anos, permitindo o bom projeto e planejamento dessa tipologia de infra-estruturas; Uma vez em uma realidade regional, promove um aumento considerável dos padrões da vida das aglomerações urbanas.
\end{abstract}

PALAVRAS-CHAVE: Design; Agitação marítima; Planejamento; Portos; Planejamento espacial. 


\section{REFERENCES}

Adam, E. F., Brown, S., Nicholls, R. J., \& Tsimplis, M. (2016). A systematic assessment of maritime disruptions affecting UK ports, coastal areas and surrounding seas from 1950 to 2014. Natural Hazards, 691-713.

doi:10.1007/s11069-016-2347-4

Amador, M. d. (2010). Tipos de métodos científicos. Lisboa: FCSH, Universidade Nova de Lisboa. Retrieved from:

http://www.fcsh.unl.pt/docentes/cceiaold/images/stories/disciplinas/PhD\%20Di dactica\%20LE/tipos_met_cientificos.pdf

APRAM. (2017). Portos. Obtido de Portos da Madeira:

http://www.apram.pt/site/index.php/pt/

Becker-Weinberg, V. (2015). Portugal's legal regime on marine spatial planning and management of the national maritime space. Marine Policy, 46-53.

doi:10.1016/j.marpol.2015.06.014

Bento, A., Rusu, E., \& Soares, C. G. (2009). Wave modelling the entrance of Leixões harbour. 6o Simposio sobre el Margen Ibérico Atlántico MIA09, (pp. 241244). Oviedo, Spain.

Calado, H., Ng, K., Johnson, D., Sousa, L., Phillips, M., \& Alves, F. (2010). Marine spatial planning: Lessons learned from the Portuguese debate. Marine Policy, 1341-1349. doi:10.1016/j.marpol.2010.06.007

Castanho, R., Loures, L., Fernández, J., andFernández-Pozo, L., (2016). Identifyingcriticalfactors for success in Cross BorderCooperation (CBC) developmentprojects. Habitat International.

Castanho, R., Loures, L., Fernández, J., andFernández-Pozo, L., (2017). Cross BorderCooperation (CBC) in Southern Europe - Anlberian Case Study. The Eurocity Elvas-Badajoz. Sustainability, 9,360; DOI:10.3390/SU9030360.

Conde, J. M., Fortes, C. J., Lemos, R., \& Reis, R. (2013). Ensaios Experimentais de Ondas Irregulares com Rebentação. 8.as Jornadas Portuguesas de Engenharia. Lisboa: LNEC, PIANC. Obtido de http://repositorio.Inec.pt:8080/jspui/handle/123456789/1005362

Cunha, P., \& Pinto, F. T. (2010). Dimensionamento optimizado de quebramares de taludes. 5.as Jornadas de Hidráulica, Recursos Hídricos e Ambiente. Porto: FEUP. 
DGPM. (2011). Plano de Ordenamento do Espaço Marítimo (POEM). Lisboa:

DGPM. Obtido de https://www.dgpm.mm.gov.pt/ordenamento-e-maritimo

Diab, H., Younes, R., \& Lafon, P. (2017). Survey of research on the optimal design of sea harbours. International Journal of Naval Architecture and Ocean Engineering, 460-472. doi:10.1016/J.IJNAOE.2016.12.004

Didier, E., \& Neves, M. d. (2010). Modelação de estruturas marítimas usando um modelo numérico Smoothed Particle Hydrodynamics. Journal of Integrated Coastal Zone Management, 435-455. Obtido de http://www.aprh.pt/rgci/pdf/rgci-211_Didier.pdf

Djouder, F., \& Boutiba, M. (2017). Vulnerability assessment of coastal areas to sea level rise from the physical and socioeconomic parameters: case of the Gulf Coast of Bejaia, Algeria. Arabian Journal of Geosciences. doi:10.1007/s12517-0173062-5

Fernandes, M. d., Esteves, T. C., Oliveira, E. R., \& Alves, F. L. (2017). How does the cumulative impacts approach support Maritime Spatial Planning? Ecological Indicators, 189-202. doi:10.1016/j.ecolind.2016.09.014

Ferreira, C., Silva, P., Fernández-Fernández, S., Baptista, P., Abreu, T., Romão, S., . . Bertin, X. (2017). Modelação da agitação marítima na região da Figueira da Foz. 4a Conferência sobre Morfodinâmica Estuarina e Costeira - MEC2017. Porto: CESAM.

Fortes, C., Capitão, R., Neves, M., \& Coli, A. B. (2004). Caracterização e propagação da agitação marítima na praia de Porto Santo, Madeira. Revista "Recursos Hídricos". Associação Portuguesa de Recursos Hídricos (APRH), 25-42.

Fortunato, A., Freire, P., Bertin, X., Rodrigues, M., Liberato, M., \& Ferreira, J. (2016). Inundação das margens do estuário do Tejo: o caso da tempestade de fevereiro de 1941. 4as Jornadas de Engenharia Hidrográfica, (pp. 143-146). Lisboa, Portugal.

França, J. A., \& Almeida, A. B. (2003). Plano regional de água da Madeira. Síntese do diagnóstico e dos objectivos.

IHB. (2005). Manual on Hydrography. Monaco: International Hydrographic Bureau. http://www.ihcantabria.com/en/servicios/puertos-infraestructuras/item/392 
Instituto Hidrográfico. (2016). Actas das 4.as Jornadas de Engenharia Hidrográfica. Lisboa: Instituto Hidrográfico.

Instituto Hidrográfico. (2016). Capítulo 3. Informação Suplementar sobre Marés. Lisboa: Instituto Hidrográfico. Retrieved from:

http://www.hidrografico.pt/download-tabelas-mare.php

Lencastre, A., \& Franco, F. M. (2006). Lições de Hidrologia 3ạ edição revista. Lisboa: Fundação da Faculdade de Ciências e Tecnologia da Universidade Nova de Lisboa.

Levy, J. S. (2008). Case Studies - Types, Designs and Logics of Inference. Conflict Management and Peace Science, 1-18. doi:10.1080/07388940701860318

Lopes, H. G., Pinto, F. T., Gomes, F. V., \& Sanchez, R. M. (2010). Técnicas de processamento de imagem vídeo para análise da interação onda-estrutura entre quebramares destacados e estruturas portuarias. 5.as Jornadas de Hidráulica, Recursos Hídricos e Ambiente. Porto: FEUP.

Meiner, A. (2010). Integrated maritime policy for the European Union consolidating coastal and marine information to support maritime spatial planning. Journal of Coastal Conservation, 1-11. doi:10.1007/s11852-009-0077-4

Oliveira, J. N., Oliveira, F., \& Teixeira, A. T. (2016). Agitação marítima e potencial de transporte sedimentar longitudinal a sul da embocadura do rio Mondego. 4as Jornadas de Engenharia Hidrográfica. Lisboa, Portugal.

Oliveira, R. P., Almeida, A. B., Sousa, J., Pereira, M. J., Portela, M. M., Coutinho, M. A., . . Lopes, S. (2011). A avaliação do risco de aluviões na ilha da Madeira. 10 Simpósio de Hidráulica e Recursos Hídricos dos Países de Língua Oficial Portuguesa (10은 LUSBA) (pp. 1-20). IST, UMa \& LREC. Retrieved from: https://www.researchgate.net/publication/244994405

Patra, S. K., Mishra, P., Mohanty, P. K., Pradhan, U. K., Panda, U. S., Murthy, M. V., ... Nair, T. M. (2016). Cyclone and monsoonal wave characteristics of northwestern Bay of Bengal: long-term observations and modeling. Natural Hazards, 1051-1073. doi:10.1007/s11069-016-2233-0

Peng, W., Zhang, Z., Gogos, G., \& Gazonas, G. (2011). Fluid Structure Interactions for Blast Wave Mitigation. Journal of Applied Mechanics. doi:10.1115/1.4002758 
Taludes. Revista de Engenharia Civil, 95-111. Retrieved from:

http://www.civil.uminho.pt/revista/artigos/Num16/Pag\%2095-111.pdf

Pullen, J., Caldeira, R., D. Doyle, J., May, P., \& Tomé, R. (2017). Modeling the airsea feedback system of Madeira Island. Journal of Advances in Modeling Earth Systems, 1-24. doi:10.1002/2016MS000861

Ramalho, R., Brum da Silveira, A., Fonseca, P., Madeira, J., Cosca, M., Cachão, M., ... Prada, S. (2015). The emergence of volcanic oceanic islands on a slow-moving plate: The example of Madeira Island, NE Atlantic. Geochemistry Geophysics Geosystems, 522-537. doi:10.1002/2014GC005657

Ribeiro, M. L., \& Ramalho, M. (2009). Uma Visita Geológica ao Arquipélago da Madeira. Lisboa: Direção Regional do Comércio, Indústria e Energia e Laboratório Nacional de Energia e Geologia, I. P.

Romão, S., Silva, P., Baptista, P., Bouzas, A. F., Fernández-Fernández, S., Ferreira, C., . . . Coelho, C. (2017). Dependência da morfologia de uma embocadura na agitação marítima. 4a Conferência sobre Morfodinâmica Estuarina e Costeira MEC2017. Porto, Portugal.

Sánchez-Arcilla, A., Sierra, J. P., Brown, S., Casas-Prat, M., Nicholls, R. J., Lionello, P., \& Conte, D. (2017). A review of potential physical impacts on harbours in the Mediterranean Sea under climate change. Regional Environmental Change, 2471-2484. doi:0.1007/s10113-016-0972-9

Sanger Institute. (2017). Carol. Retrieved from: Sanger Institute: http://www.sanger.ac.uk/science/tools/carol

Schaefer, N., \& Barale, V. (2011). Maritime spatial planning: opportunities \& challenges in the framework of the EU integrated maritime policy. Journal of Coastal Conservation, 237-245. doi:10.1007/s11852-011-0154-3

Sousa, I. A., Santos, J. A., \& Reis, M. T. (2004). Dimensionamento do manto de quebre-mares de taludes utilizando métodos probabilísticos de nível II. 7oㅡ Congresso da Água. Lisboa: APRH. Obtido de http://www.aprh.pt/congressoagua2004/PDF/20.PDF

Stelzenmüller, V., Gimpel, A., Gopnik, M., \& Gee, K. (2017). Aquaculture SiteSelection and Marine Spatial Planning: The Roles of GIS-Based Tools and Models. Aquaculture Perspective of Multi-Use Sites in the Open Ocean, 131-148. 
Tsilimigkas, G., \& Rempis, N. (2017). Maritime spatial planning and spatial planning: Synergy issues and incompatibilities. Evidence from Crete island, Greece. Ocean \& Coastal Management, 33-41.

doi:10.1016/j.ocecoaman.2017.02.001

Tudor, M., \& Ramos-Pereira, A. (2015). A dinâmica de uma praia encastrada durante o inverno marítimo de 2013-2014. O exemplo da Praia da Adraga. VII Congresso Nacional de Geomorfologia, Geomorfologia 2015. Lisboa, Portugal.

Vivero, J. L., Mateos, J. C., \& Corral, D. F. (2009). Geopolitical factors of maritime policies and marine spatial planning: State, regions, and geographical planning scope. Marine Policy, 624-634. doi:10.1016/j.marpol.2008.12.010

Yin, R. K. (1994). Case Study Research: Design and Methods. London: SAGE Publications.

Zaucha, J. (2014). Sea basin maritime spatial planning: A case study of the Baltic Sea region and Poland. Marine Policy, 34-45. doi:10.1016/j.marpol.2014.05.003

Zheng, C., Zhang, R., Shi, W., Li, X., \& Chen, X. (2017). Trends in Significant Wave Height and Surface Wind Speed in the China Seas Between 1988 and 2011. Journal of Ocean University of China, 717-726. doi:10.1007/s11802-017-3213-z

Recebido: 03 set. 2017

Aprovado: 09 out. 2017.

DOI: $10.3895 /$ rbpd.v7n1.7136

Como citar: GONÇALVES, R. S.; CAMACHO, R. F.; LOUSADA, S.; CASTANHO, R. A. Modeling of maritime agitation for the design of maritime infraestructures: the case study of madeira archipelago. R. bras. Planej. Desenv.,Curitiba, v. 7, n. 1, p. 29-50, jan./abr. 2018. Disponível em: <https://periodicos.utfpr.edu.br/rbpd>. Acesso em: XXX.

Correspondência:

Rui Alexandre Castanho

Avda. de Elvas, s/n, 06071 Badajoz, Espanha

Direito autoral: Este artigo está licenciado sob os termos da Licença CreativeCommons-Atribuição 4.0

Internacional. 